\title{
The French Depression in the 1930s
}

\author{
Paul Beaudry and Franck Portier
}

In studying the French Depression of the 1930s, our objective is to help build a better general understanding of the Depression era. In particular, our approach is to compare the French episode with that of the U.S. Great Depression and to use the modern tools of macroeconomics to analyze the French experience. In doing so, we help extend the number of depression episodes studied using a methodology similar to that pioneered in the work of Cole and Ohanian (1999a, 1999b) and Prescott (1999).

This paper arrives at three conclusions. First, counter to the conventional view regarding the French Depression, there are more similarities than differences between the French and U.S. episodes in the 1930s, which suggests the need for a common explanation. Second, technological change (regression or stagnation) is neither sufficient nor necessary to account for the French Depression. This is shown in two ways: using a structural model and doing some growth accounting. Third, institutional change and market regulation may be key to understanding the Depression. In particular, we show that such an explanation is quantitatively relevant, but the causes of those changes are still to be explained.

\section{Overview of French Interwar History}

This section describes the main lines of French political and economic history of the interwar period that bear on the data. Our sources are the work of Asselain (1995), Beltran and Griset (1994), Flamant (1989), Hautcoeur (1997), and Villa (1993).

\section{Broad Overview}

Figure 1 presents an evaluation of French gross domestic product (GDP) in 1938 francs. The broad overview shows rapid growth in the 1920s, a sharp 
Figure 1. French GDP, 1919-39

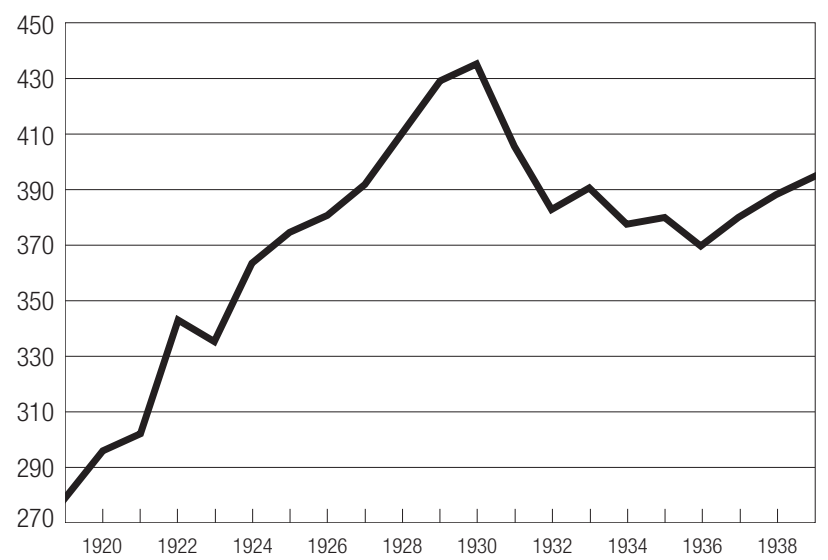

decline from 1930 to 1932 , then a mild decline from 1932 to 1936 and a slow recovery toward the eve of World War II. This is the picture that most economists and historians of the period have in mind.

\section{Post-World War I Period (1919-30)}

One observes in 1919 the traditional picture of a country after a war: large destruction of capital, high public debt, and inflation. In 1919, France was said to be "victorious but ruined." War damages were estimated to be 113 percent of 1913 GDP. Sixty percent of those damages were represented by the destruction of productive capital, housing capital, and land. French public debt reached 170 percent of GDP in 1919, compared to 66 percent in 1913. Prices tripled during the war. The French franc depreciated between 1919 and 1920: it was exchanged against twenty-five pounds sterling in 1913, compared to forty-two in December 1919 and sixty in December 1920.

French growth was rapid in the 1920s, despite a short worldwide recession in 1921. This growth was accompanied by a continuous depreciation of the French franc. Depreciation accelerated with the Cartel des Gauches government, a coalition of Socialists and Radicaux (center-left party). The political cost of depreciation became too large, and in 1926 former president Raymond Poincaré was designated as the new prime minister (Président du Conseil) of a right-wing coalition. This government implemented a strict stabilization policy with public investment reductions, public consumption stabilization, and increases in taxes and tariffs. After a final devaluation in June 1928, the French franc stabilized at a level of one-fifth of its 1913 gold value. 


\section{Great Depression (1931-36)}

The French Depression is considered relatively mild (Hautcoeur 1997). At its peak, unemployment did not exceed one million, less than 5 percent of the 1930 workforce. The fall in production was also relatively modest and never reached 20 percent of the 1929 output in commerce and manufactures. The Depression in France was not accompanied by a banking crisis, as only one major bank failed. Starting in 1931, many countries decided to devaluate their currency. The pound sterling was devalued in 1931 and the U.S. dollar in 1933. As stressed by Asselain (1995), for political reasons, French governments rejected the options of devaluation and capital controls. Despite the inflow of gold (one-third of the world stock of gold was in France in 1933) and the relative price increase that followed, France did not devalue. Furthermore, the government led by Pierre Laval decided in 1935-36 to implement a strict deflationary policy. A 1935 act reduced by 10 percent all public expenditures, including civil servant compensation. Some controlled prices were cut (bread, housing rents) and taxes were increased.

In May 1936, a coalition of Socialists and Communists won the elections, and the Socialist leader Léon Blum became Président du Conseil in June. The new labor market regulations imposed by the Front Populaire provoked a large increase in the cost of labor. First, the government imposed collective bargaining on wage contracts between employers and trade unions. Second, the workweek was reduced from forty-eight to forty hours, keeping the weekly or monthly wage constant. Third, workers were granted two weeks of paid holidays, again keeping the weekly or monthly wage constant. Fourth, the civil servant wage cut was suspended. At the same time, a nationwide strike movement led to the Accords de Matignon, where wages were increased by 12 percent on average. It seems that these strikes and their effect on wages were not anticipated by the government. All in all, labor cost increased by 29 percent: 12 percent because of the Accords de Matignon, 4 percent because of paid holidays, 10.8 percent because of the forty-hour workweek. At the same time, the French franc was devalued by 30 percent. In 1937, the first public budget of the Front Populaire increased tax progressiveness but decreased average taxes, from 17.4 percent to 15.8 percent of GDP.

\section{Eve of World War II (1937-39)}

Following the implementation of the forty-hour workweek and a drop in investment, the economy weakly recovered. By 1938, the economy entered a prewar regime. Public expenditures increased by 122 percent. The workweek increased by one hour in November 1938, and the workweek increased to sixty hours for "strategic industries." 
Figure 2. Undetrended levels of French and U.S. real GDP, $1929-39(1929=100)$

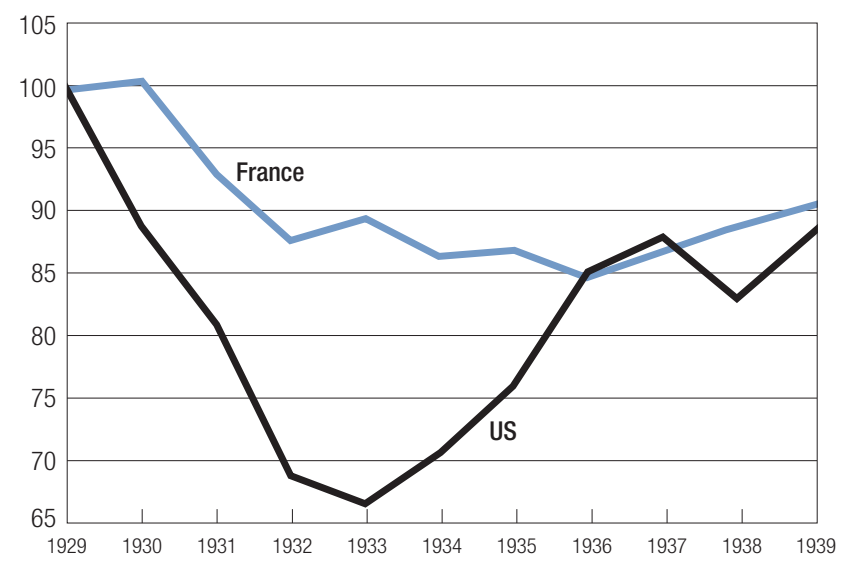

\section{Summary}

Four basic points should be kept in mind. First, the Depression started one year later in France than it did in the United States. Second, there was no major banking crisis in France. Third, there was no deflationary policy before 1934. Fourth, at the trough of the recession in 1936, a major program of reforms was implemented, which mirrored the 1933 New Deal program in the United States.

\section{Inspecting the Data}

In this study, we use Pierre Villa's (1993) data, which are generally seen as the best economic data for the interwar period (see Data Appendix). The data for 1939 should be interpreted with caution, as war was declared on September 1939 and preparations for the war had occurred earlier that year.

Figure 2 presents the comparison of real GDP in France and the United States, both normalized to 100 in 1929. It illustrates the conventional wisdom among economists and historians: the Depression came later in France, was less severe, but lasted longer.

\section{Detrending}

The depth of the Depression should be evaluated in relation to the "normal" growth rate of the economy. How do we calculate this "normal" rate? For the United States, Cole and Ohanian (1999a) use the average growth rate of per capita gross national product (GNP) over the sample period 1919-97, excluding the Great Depression and World War II (1930-46). They find a 


\section{Table 1. Average yearly growth rate of per capita GDP} (1914-18 and 1939-45 excluded)

\begin{tabular}{lc}
\hline & Growth rate (\%) \\
\hline By subperiods & \\
$1896-1913$ & 1.25 \\
$1919-29$ & 3.53 \\
$1930-39$ & -.30 \\
$1946-94$ & 3.46 \\
& \\
Average & \\
All sample (1896-1994) & 2.54 \\
Excluding 1930-39 & 2.98 \\
Excluding 1930-39 and pre-WWI & 3.47 \\
Pre-Great Depression (1896-1929) & 2.15 \\
\hline
\end{tabular}

value of 1.90 percent per year. The choice of the growth rate will greatly influence the evaluation of the depth and persistence of the Depression.

Table 1 presents average growth rates of French per capita GDP for different subperiods. We use total population to compute the per capita series.

Following the work of Cole and Ohanian (1999a), we use the entire available sample except for Depression years to compute the average growth rate of output. This growth rate is 2.98 percent. Note that this is a conservative

Figure 3. Detrended levels of French and U.S. real GDP per capita, using different trends for the two countries, 1929-39 $(1929=100)$

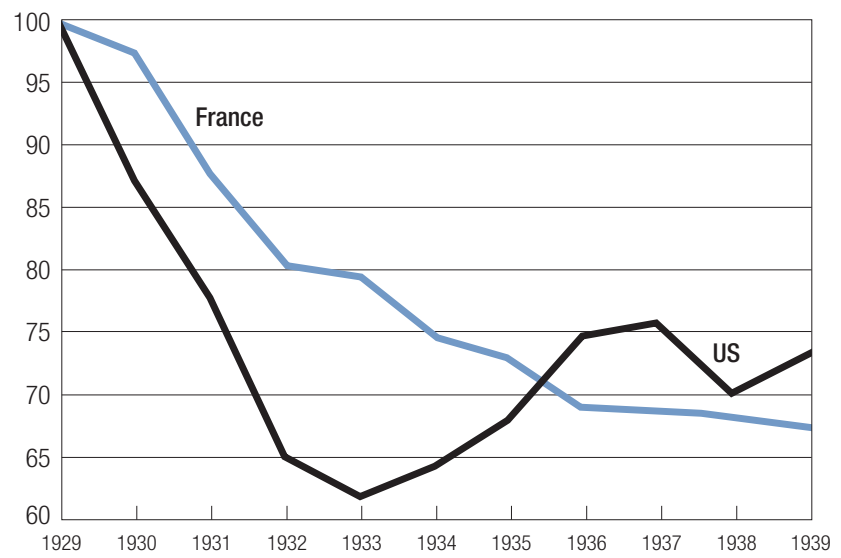


value compared to what economic agents would have thought in 1929 if they extrapolated the 1919-29 trend (3.53 percent).

Figure 3 compares U.S. GNP taken from the work of Cole and Ohanian (1999a) and French detrended GDP per capita. The pattern of the French Great Depression is now very different and is more in line with the U.S. Depression. The U.S. Depression is temporarily deeper (in the trough of 1933), but at the end of the period (say after 1936), detrended levels are roughly the same, about 30 percent below trend, France being in a slightly worse position than the United States. In both countries in 1939, detrended output has about the same value as in 1936: growth is close to its long-run value, whereas levels are permanently 30 percent below what would have been expected in 1929 had growth stayed constant.

This striking similarity between the two countries' dynamic pattern is not an artifact of our choice for the long-run trend, and it can be seen in Figure 4 that the qualitative picture is the same when the same trend as that for the United States (1.9 percent) is also chosen for France.

Table 2 compares undetrended per capita French GDP to undetrended measures for the United States and for an international average (Belgium, Britain, France, Germany, Italy, Japan, and Sweden), as given in the work of Cole and Ohanian (1999a). Note that the French Depression, if milder than the U.S. Depression in 1933, is sharper and more persistent than the international average.

Figure 4. Detrended levels of French and U.S. real GDP per capita, using U.S. trend for the two countries, $1929-39(1929=100)$

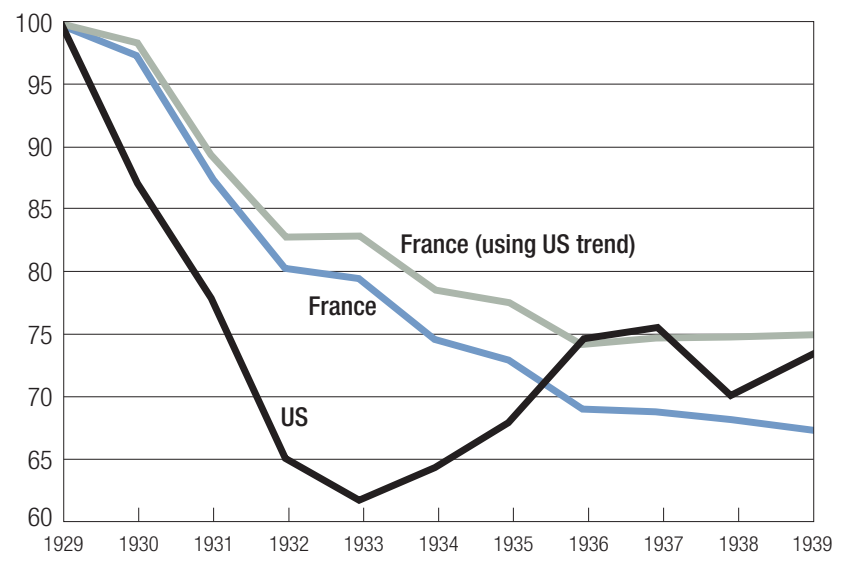


Table 2. International comparison

(per capita, undetrended, $1929=100$ )

\begin{tabular}{lccc}
\hline Year & U.S. & $\begin{array}{c}\text { International } \\
\text { average }\end{array}$ & France \\
\hline 1932 & 69.0 & 91.3 & 87.8 \\
1933 & 66.7 & 94.5 & 89.5 \\
1935 & 76.3 & 101.0 & 87.0 \\
1938 & 83.6 & 112.4 & 88.8 \\
\hline
\end{tabular}

\section{Output and Components}

Let us first inspect levels of output per capita and their components (Table $3)$. In what follows we use the expenditure-based data for GDP. Series are all normalized to one hundred in 1929.

The undetrended measures presented in Table 3 show the collapse of exports and imports, the relative mildness of the Depression from 1930 to 1932 and the long period of output stagnation from 1932 to 1935, the trough in 1936, and then the recovery at the steady growth rate. Table 4 presents detrended measures of output components. One can observe the large decline in investment - its level from 1935 to 1938 is about 55 percent below trend. Also, note the tremendous increase in public expenditures just before World War II with simultaneous reduction of other components of aggregate demand shares in 1938 and 1939. Table 5 shows that the share of imports in output stayed constant over the period, while the share of exports declined. Excluding 1939, the consumption share increased while the investment share

Table 3. Undetrended per capita levels of output and components

\begin{tabular}{rrrrrrr}
\hline Year & Output & Private Cons. & Private Inv. & Govt. Purch. & Exports & Imports \\
\hline 1929 & 100.0 & 100.0 & 100.0 & 100.0 & 100.0 & 100.0 \\
1930 & 100.5 & 96.9 & 120.6 & 112.9 & 89.0 & 106.5 \\
1931 & 93.1 & 97.0 & 89.4 & 137.9 & 75.0 & 104.4 \\
1932 & 87.8 & 96.4 & 64.7 & 149.1 & 57.6 & 87.4 \\
1933 & 89.5 & 100.0 & 62.5 & 146.3 & 58.9 & 91.0 \\
1934 & 86.5 & 95.1 & 57.2 & 139.6 & 60.8 & 78.3 \\
1935 & 87.0 & 95.9 & 54.2 & 170.1 & 54.8 & 76.1 \\
1936 & 84.8 & 93.8 & 54.4 & 180.4 & 52.2 & 83.6 \\
1937 & 87.0 & 94.4 & 61.8 & 183.7 & 56.2 & 88.7 \\
1938 & 88.8 & 98.1 & 48.7 & 186.3 & 60.8 & 79.1 \\
1939 & 90.5 & 91.0 & 46.0 & 371.6 & 58.9 & 69.5 \\
\hline
\end{tabular}


Table 4. Detrended per capita levels of output and components

\begin{tabular}{rrrrrrr}
\hline Year & Output & Private Cons. & Private Inv. & Govt. Purch. & Exports & Imports \\
\hline 1929 & 100.0 & 100.0 & 100.0 & 100.0 & 100.0 & 100.0 \\
1930 & 97.6 & 94.1 & 117.1 & 109.7 & 86.4 & 103.5 \\
1931 & 87.8 & 91.4 & 84.3 & 130.1 & 70.8 & 98.5 \\
1932 & 80.4 & 88.3 & 59.2 & 136.5 & 52.8 & 80.0 \\
1933 & 79.6 & 88.9 & 55.5 & 130.1 & 52.4 & 80.9 \\
1934 & 74.7 & 82.1 & 49.4 & 120.5 & 52.5 & 67.6 \\
1935 & 73.0 & 80.4 & 45.4 & 142.6 & 46.0 & 63.8 \\
1936 & 69.0 & 76.4 & 44.3 & 146.9 & 42.5 & 68.1 \\
1937 & 68.8 & 74.6 & 48.9 & 145.3 & 44.4 & 70.1 \\
1938 & 68.2 & 75.3 & 37.4 & 143.0 & 46.7 & 60.7 \\
1939 & 67.5 & 67.8 & 34.3 & 277.0 & 43.9 & 51.8 \\
\hline
\end{tabular}

Table 5. Shares of output (\%)

\begin{tabular}{lccccc}
\hline Year & Private Cons. & Private Inv. & Govt. Purch. & Exports & Imports \\
\hline 1929 & 75 & 23 & 4 & 12 & 13 \\
1930 & 73 & 27 & 4 & 10 & 14 \\
1931 & 78 & 22 & 5 & 9 & 15 \\
1932 & 83 & 17 & 6 & 8 & 13 \\
1933 & 84 & 16 & 6 & 8 & 14 \\
1934 & 83 & 15 & 6 & 8 & 12 \\
1935 & 83 & 14 & 7 & 7 & 12 \\
1936 & 83 & 14 & 8 & 7 & 13 \\
1937 & 82 & 16 & 8 & 7 & 14 \\
1938 & 83 & 12 & 7 & 8 & 12 \\
1939 & 76 & 11 & 15 & 7 & 10 \\
\hline
\end{tabular}

decreased. Compared to 1929, it seems that the economy had reached in the late 1930s a new balanced-growth path with a lower capital-output ratio and a larger consumption-output ratio.

Table 6 shows that household investment was the most affected component of investment and that the increase in government expenditures can mainly be attributed to consumption, not investment. Table 7 shows that a decline in consumption started in 1929, except for manufactured goods.

\section{Input Measures}

Table 8 shows the effect of the 1936 accords on workweek length and the drop in hours worked. Note that employment did not vary significantly after 
Table 6. Detrended per capita levels of investment and public consumption

\begin{tabular}{lcrrc}
\hline Year & Household I. & Firms I. & Govt. I. & Govt. Cons. \\
\hline 1929 & 100.0 & 100.0 & 100.0 & 100.0 \\
1930 & 134.4 & 110.2 & 100.1 & 114.9 \\
1931 & 89.6 & 82.3 & 112.5 & 139.6 \\
1932 & 74.3 & 53.2 & 111.6 & 150.0 \\
1933 & 61.1 & 53.3 & 99.9 & 146.5 \\
1934 & 60.3 & 45.1 & 88.0 & 138.1 \\
1935 & 57.1 & 40.8 & 104.6 & 163.2 \\
1936 & 41.1 & 45.6 & 94.8 & 175.1 \\
1937 & 33.9 & 54.8 & 75.2 & 183.2 \\
1938 & 30.2 & 40.2 & 70.2 & 182.5 \\
1939 & 24.9 & 38.0 & 60.9 & 394.1 \\
\hline
\end{tabular}

Table 7. Detrended per capita levels of household consumption components

\begin{tabular}{lccrr}
\hline Year & $\begin{array}{c}\text { Agricultural } \\
\text { goods }\end{array}$ & $\begin{array}{c}\text { Manufactured } \\
\text { goods }\end{array}$ & Services & Housing \\
\hline 1929 & 100.0 & 100.0 & 100.0 & 100.0 \\
1930 & 83.9 & 109.0 & 96.1 & 97.3 \\
1931 & 89.4 & 90.8 & 97.3 & 94.4 \\
1932 & 86.8 & 88.2 & 91.0 & 92.0 \\
1933 & 84.7 & 96.8 & 87.0 & 89.4 \\
1934 & 85.5 & 74.7 & 83.1 & 86.8 \\
1935 & 80.7 & 75.3 & 86.8 & 84.5 \\
1936 & 71.7 & 75.8 & 89.3 & 82.0 \\
1937 & 72.2 & 71.8 & 85.4 & 79.5 \\
1938 & 74.1 & 74.2 & 80.1 & 76.9 \\
1939 & 67.0 & 65.4 & 71.4 & 74.6 \\
\hline
\end{tabular}

1932. Again, it seems that in 1936-39 the economy was on a new steady growth path where hours were about 25 percent lower than before the Depression. Capacity utilization collapsed in 1930 and 1931 and then stayed relatively constant.

\section{Money and Prices}

In Table 9 one does not observe any strong contractionary monetary policy, except for the Laval's deflation in 1935 and early 1936. Nevertheless, the 
Table 8. Input measures (per capita, $1929=100$ except $(\Gamma)$ in level)

\begin{tabular}{ccccc}
\hline Year & Employment & $\begin{array}{c}\text { Workweek } \\
\text { length }\end{array}$ & $\begin{array}{c}\text { Hours } \\
\text { worked }\end{array}$ & $\begin{array}{c}\text { Capacity } \\
\text { utilization }\end{array}$ \\
\hline 1929 & 100.0 & 100.0 & 100.0 & 97.5 \\
1930 & 99.0 & 98.0 & 97.1 & 90.3 \\
1931 & 95.9 & 94.9 & 91.0 & 84.8 \\
1932 & 92.4 & 91.9 & 85.0 & 77.7 \\
1933 & 92.3 & 93.6 & 86.4 & 79.9 \\
1934 & 91.1 & 93.0 & 84.7 & 77.6 \\
1935 & 90.3 & 92.6 & 83.7 & 76.2 \\
1936 & 90.2 & 94.1 & 84.8 & 77.3 \\
1937 & 91.4 & 83.9 & 76.6 & 77.9 \\
1938 & 92.1 & 81.5 & 75.1 & 76.2 \\
1939 & 92.8 & 83.9 & 77.8 & 79.6 \\
\hline
\end{tabular}

Table 9. Nominal and real monetary variables

(per capita and ( $[$ ) detrended)

\begin{tabular}{|c|c|c|c|c|}
\hline Year & M2 & $\begin{array}{l}\text { GDP } \\
\text { deflator }\end{array}$ & $\begin{array}{l}\text { Money market } \\
\text { rate }\end{array}$ & $\mathrm{M} 2 / P(\lceil)$ \\
\hline 1929 & 100.0 & 100.0 & 3.5 & 100.0 \\
\hline 1930 & 105.1 & 105.4 & 2.7 & 96.9 \\
\hline 1931 & 110.5 & 104.2 & 2.1 & 100.0 \\
\hline 1932 & 108.4 & 97.6 & 2.5 & 101.7 \\
\hline 1933 & 102.9 & 93.7 & 2.5 & 97.6 \\
\hline 1934 & 98.2 & 89.2 & 2.7 & 95.1 \\
\hline 1935 & 95.5 & 82.5 & 3.4 & 97.1 \\
\hline 1936 & 98.1 & 85.9 & 3.7 & 93.0 \\
\hline 1937 & 106.9 & 107.7 & 3.8 & 78.5 \\
\hline 1938 & 121.2 & 122.0 & 2.7 & 76.3 \\
\hline 1939 & 161.4 & 129.0 & 2.0 & 93.3 \\
\hline
\end{tabular}

GDP deflator decreased from 1931 to 1936. As usual, deflation was sharper for the producer price index (PPI). Note that price deflation stopped after 1935 and that 1936-39 were years of high inflation (Table 10).

\section{Real Wage}

In Table 11, one can observe a continuous increase in the real wage paid by firms (the nominal wage divided by the producer price index) up to 1936, which then stayed constant in deviations from trend (excluding 1939). Note in 
Table 10. Prices

\begin{tabular}{rrrrr}
\hline Year & $\begin{array}{c}\text { GDP } \\
\text { deflator }\end{array}$ & CPI & $\begin{array}{c}\text { Wholesale price } \\
\text { index }\end{array}$ & $\begin{array}{c}\text { Producer price } \\
\text { index }\end{array}$ \\
\hline 1929 & 100.0 & 100.0 & 100.0 & 100.0 \\
1930 & 105.4 & 103.5 & 87.1 & 99.8 \\
1931 & 104.2 & 100.4 & 74.1 & 94.6 \\
1932 & 97.6 & 93.6 & 65.3 & 88.1 \\
1933 & 93.7 & 90.6 & 62.3 & 85.6 \\
1934 & 89.2 & 86.4 & 58.8 & 83.4 \\
1935 & 82.5 & 80.6 & 55.7 & 80.0 \\
1936 & 85.9 & 84.0 & 64.9 & 80.1 \\
1937 & 107.7 & 104.8 & 90.4 & 99.3 \\
1938 & 122.0 & 118.4 & 102.5 & 115.6 \\
1939 & 129.0 & 126.5 & 113.7 & 126.4 \\
\hline
\end{tabular}

Table 11. Real wage, $(\Gamma)=$ undetrended

\begin{tabular}{lrcccc}
\hline Year & GDP & $\begin{array}{c}\text { Real wage } \\
\text { (using CPI) }\end{array}$ & $\begin{array}{c}\text { Real wage } \\
\text { (using PPI) }\end{array}$ & $\begin{array}{c}\text { Real wage }(\Gamma) \\
\text { (using CPI) }\end{array}$ & $\begin{array}{c}\text { Real wage }(\Gamma) \\
\text { (using PPI) }\end{array}$ \\
\hline 1929 & 100.0 & 100.0 & 100.0 & 100.0 & 100.0 \\
1930 & 97.6 & 101.3 & 105.0 & 104.3 & 108.1 \\
1931 & 87.8 & 101.2 & 107.4 & 107.3 & 113.8 \\
1932 & 80.4 & 100.5 & 106.8 & 109.7 & 116.6 \\
1933 & 79.6 & 100.7 & 106.6 & 113.3 & 119.9 \\
1934 & 74.7 & 101.1 & 104.8 & 117.1 & 121.3 \\
1935 & 73.0 & 105.6 & 106.2 & 125.9 & 126.7 \\
1936 & 69.0 & 111.4 & 116.8 & 136.8 & 143.4 \\
1937 & 68.8 & 106.2 & 112.0 & 134.3 & 141.7 \\
1938 & 68.2 & 107.4 & 110.0 & 139.9 & 143.2 \\
1939 & 67.5 & 102.6 & 102.7 & 137.7 & 137.8 \\
\hline
\end{tabular}

particular the large increase at the time of the Front Populaire in 1936 - from 126 to 143 in levels (100 being the level in 1929). The purchasing power of the nominal wage, as defined by the nominal wage divided by the consumer price index (CPI), did not increase that much in 1936, as the devaluation contributed to a larger increase in the CPI ( 40 percent increase in 1936 versus 24 percent for the PPI).

The striking feature of Table 11 is that the real wage was above trend during the entire Depression. The real wage relative to the PPI increased more 
than 5 percent above trend in 1930, stayed roughly flat until 1936, and then temporarily increased.

\section{Similarity to the U.S. Depression}

To summarize, once both economies' output data are deflated by their own trends, we find strong similarities between the French and U.S. depressions. In 1938-39, hours were constant in both countries at approximately 25 percent below their 1929 level. Outputs were also about 30 percent below their respective trends in both countries, both growing roughly at their long-run rates. Only the sharp U.S. drop of 1931-33 and the subsequent recovery of 1933-35 are not observed in France. Taking into account that France lags the United States by one year in slipping into the Depression and that the banking crisis of 1931-33 was not observed in France, the picture is surprisingly similar. Finally, in both countries, the investment-output ratio seems to be permanently lower after the Depression (see Cole and Ohanian 1999a, Table 3, for the United States).

These results cast doubt on the conventional wisdom about the French Depression that is summarized by the following:

The Great Depression in France was unique: it began more slowly than in the other industrial countries, was less severe but lasted longer. The main reasons for these special features are the evolution of the exchange rate (under and later overvalued), policy errors, exposure to foreign competition, and dependence on foreign markets. (Hautcoeur 1997)

As we have shown, the French Depression is not milder when considered as deviation from a steady growth path. To put it differently, things went very badly compared to what would have been expected in 1930 .

The second main feature of this conventional wisdom is the importance attributed to exchange rate fluctuations. The 1926 Poincaré stabilization of the French franc at an undervalued level is conventionally seen as an important reason for the relative high growth in France and for its insulation from the Great Depression in 1929 and 1930. The Depression of 1931-36 is mainly attributed to the U.K. and U.S. devaluations of 1931 and 1933. The story goes like this: France was insulated from the Depression in 1929 and 1930 because of the undervaluation of the French franc. The devaluation of the pound sterling in 1931 and the U.S. dollar in 1933 are seen as the two shocks that triggered the recession. Laval's deflation of 1935-36 is interpreted as the wrong solution to the problem, the correct one being devaluation. Then, the Front Populaire devaluation of 1936 restored competitiveness and put the economy on a (mild) recovery path.

This story is hardly supported by the data. First, the French Depression started in 1930 and not 1931, as can be seen from the detrended data, even 
Figure 5. TFP measures, $1930-39(1930=100)$

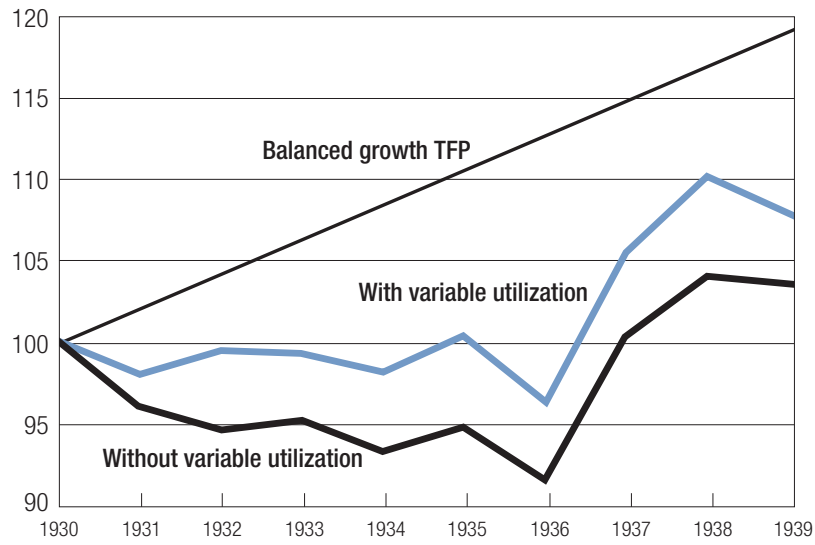

though the drop in output is smaller than in the United States. Second, there is no acceleration of the Depression in 1933. Third, international trade is a small share of output, and with reasonable substitutability between domestic and imported intermediate goods, could not account for a significant fraction of output drop.

Finally, absent financial intermediation shocks, the conduct of monetary policy was accommodating (see Table 9) until 1935-real money, as measured by M2, divided by the GDP deflator, stayed almost constant from 1929 to 1935-and fell only with the Laval's deflationary policy.

It seems that the idiosyncrasies attributed to the French Depression do not stand up to a close look at the data and that we should look for a common, or at least similar, cause for both the French and U.S. episodes. Are technological factors the likely explanation? This is what we consider in the next section.

\section{Role of Technology Shocks}

\section{Growth Accounting}

We first compute total factor productivity (TFP) using Cobb-Douglas production functions $Y_{t}=A_{t}\left(X_{t} H_{t}\right)^{\alpha} K_{t}^{1-\alpha}$ and $Y_{t}=A_{t}\left(X_{t} H_{t}\right)^{\alpha}\left(z_{t} K_{t}\right)^{1-\alpha}$, where $Y$ stands for value added, $K$ for productive capital, $H$ for hours worked, $z$ for capacity utilization, and output elasticity to hours $\alpha=0.6629 . X_{t}$ is a labor augmenting deterministic trend (with growth rate $\gamma$ ), and $A_{t}$ a stationary component of total factor productivity. See the following section on calibration for a description of the computation of $\alpha$. TFP is given by $A_{t} X_{t}^{\alpha}$, where $X$ is the deterministic trend of TFP and $A$ is the deviation from the trend. The resulting series are depicted in Figure 5. 
As expected, the series computed without variable capacity utilization decreases more than the series with variable capacity utilization. In the following, we give attention to the latter measure of TFP. We observe a stop in TFP growth from 1930 to 1935, then a drop in 1936 and a strong rebound the next two years. Is this evolution sufficient for understanding output growth? Is it necessary? We answer no to both these questions in two stages, first within a structural model and then by doing some more growth accounting.

\section{Technological Stagnation}

\section{A Simple Model}

We consider a growth model with labor supply and capital depreciation in use. Time is discrete and the time unit is one year. We assume that the economy is composed of a representative household and a representative firm. All variables are per capita.

Household preferences are represented by the following intertemporal utility function $V$ :

$$
V(0)=E_{0} \sum_{t=0}^{\infty} \beta^{t}\left(\log C_{t}+\frac{\theta}{1-\eta}\left(\left(1-H_{t}\right)^{1-\eta}-1\right)\right),
$$

where $C$ is consumption. The representative firm produces according to

$$
Y_{t}=A_{t}\left(X_{t} H_{t}\right)^{\alpha}\left(z_{t} K_{t}\right)^{1-\alpha} \text {. }
$$

$X_{t}$ and $A_{t}$ processes are given by

$$
\begin{aligned}
X_{t} & =X_{0} \exp \left(\gamma_{t}\right) \\
\log A_{t} & =\rho \log A_{t-1}+\varepsilon_{t},
\end{aligned}
$$

where $\rho$ is strictly between 0 and 1 and $\varepsilon_{t}$ is a white noise.

Capital accumulates according to the following law of motion:

$$
K_{t+1}=\left(1-\delta_{t}\right) K_{t}+I_{t},
$$

where $I$ stands for investment.

As in the work of Greenwood, Hercowitz, and Huffman (1988), it is assumed that utilization increases depreciation of capital. The depreciation rate $\delta$ is endogenously given by

$$
\delta_{t}=\delta_{1} z_{t}^{\delta_{2}}
$$


with $\delta_{1}>0$ and $\delta_{2}>0$. Such a specification allows for some endogeneity of TFP if the production function is misspecified by omitting variable utilization.

In this setting with complete markets and perfect competition, the equilibrium allocations can be recovered by solving the following social planner's problem:

$$
\max V(0)
$$

$$
\text { s.t. } C_{t}+K_{t+1}=A_{t}\left(z_{t} K_{t}\right)^{\alpha}\left(X_{t} H_{t}\right)^{1-\alpha}+(1-\delta) K_{t} .
$$

The first-order conditions of this problem are given by

$$
\begin{aligned}
1 / C_{t} & =\theta\left(1-H_{t}\right)^{-\eta} \times(1-\alpha) Y_{t} / H_{t} \\
\frac{1}{C_{t}} & =E_{t}\left[\frac{\beta}{C_{t+1}}\left((1-\alpha) A_{t+1} K_{t+1}^{-\alpha}\left(X_{t+1} H_{t+1}\right)^{\alpha}+1-\delta\right)\right] \\
C_{t} & =A_{t}\left(X_{t} H_{t}\right)^{\alpha} K_{t}^{1-\alpha}+(1-\delta) K_{t}-K_{t+1}
\end{aligned}
$$

plus a transversality condition.

In such an economy, there exists a steady growth path, where growth is driven by TFP.

\section{Calibration}

The following parameters need to be calibrated in this laboratory economy: the output elasticity to hours $\alpha$, the labor disutility parameters $\eta$ and $\theta$, the discount factor $\beta$ (already divided by population growth factor), the growth rate of TFP $\gamma$, depreciation parameters $\delta_{1}$ and $\delta_{2}$, and the persistence of the technology shock $\rho$. Using the aggregate wage bill and assuming that the share of output that goes to labor is the same in firms and for self-employed, we find for the interwar period a labor share of 66 percent. Note that without the correction for self-employed, we would have found 47 percent. We therefore set $\alpha=0.66 . \delta_{1}$ and $\delta_{2}$ are chosen so that steady-state capacity utilization matches the average value during 1919-29 (83 percent) and steady-state depreciation is 10 percent. We study two economies, one with high elasticities of utilization and labor supply, one with low ones. In the high-elasticity economy, $\delta_{2}$ is close to one, whereas $\delta_{2}$ is large in the lowelasticity economy. We set the discount factor to $\beta=0.96$, as in the work of Cole and Ohanian (1999a). In the high-elasticity economy, the intertemporal 
elasticity of labor supply is assumed to be infinite $(\eta=0$, linear utility in leisure), whereas it is assumed to be one ( $\eta=1, \log$ utility in leisure) in the low-elasticity economy. $\theta$ is then chosen such that $H$ is on average one-third of total available time. We estimated an AR(1) process on deviations of total factor productivity from trend in the period 1919-39, and $\rho$ was estimated to be $0.98 . \gamma=0.0293$, so that steady growth rate of output is 2.98 percent. This calibration is summarized in Table 12 .

Finally, we assume that capital was equal to its steady-state value in 1929.

Table 12. Calibration

\begin{tabular}{lc}
\hline Output elasticity to labor $\alpha$ & .66 \\
Discount factor $\beta$ & .96 \\
Growth rate of TFP $\gamma$ & .0293 \\
Depreciation rate $\delta$ & .1 \\
Depreciation elasticity parameter $\delta_{2}$ & \\
$\quad$ High-elasticity case & .1 \\
$\quad$ Low-elasticity case & 10 \\
Share of time allocated to work $H$ & $1 / 3$ \\
Inverse of the intertemporal elasticity & \\
of substitution in labor supply $\eta$ & \\
$\quad$ High-elasticity case & \\
$\quad$ Low-elasticity case & 0 \\
Persistence of technology shock & .98 \\
\hline
\end{tabular}

\section{Predictions of the Model}

We assume that TFP behaves qualitatively as observed: growth at the steady growth rate before 1930 and after 1936, unexpected stagnation in between. Figures 6 and 7 present the dynamic response of the low- and high-elasticity economies.

What do we learn from this exercise? The decline in output is not fully reproduced. Even though the investment drop is matched before 1936, hours do not drop as they did in the data. On top of that, the slow (or absent) recovery after 1936 is missed by the model. Hence, we can conclude that TFP stagnation does not appear to be sufficient to account for the French episode, which is a conclusion similar to that found for the United States by Cole and Ohanian (1999a). In the next subsection, we go one step further and argue that technological stagnation may not even be a necessary condition for understanding the French Depression. 
Figure 6. Unexpected TFP stagnation with high elasticity, 1930-39
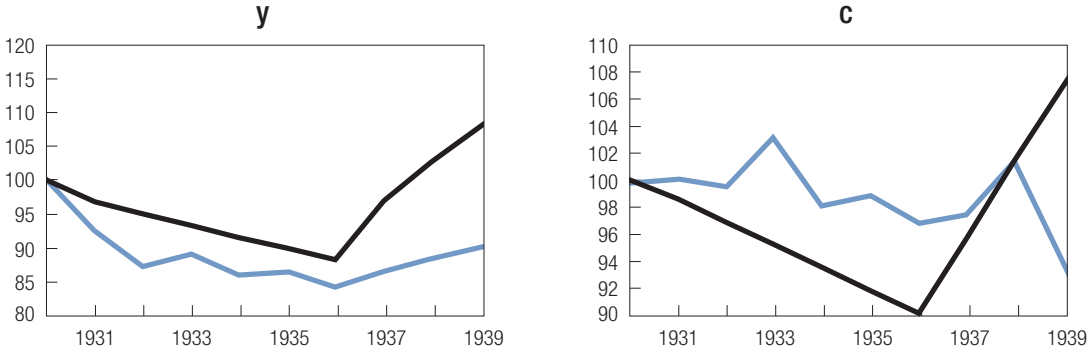

i

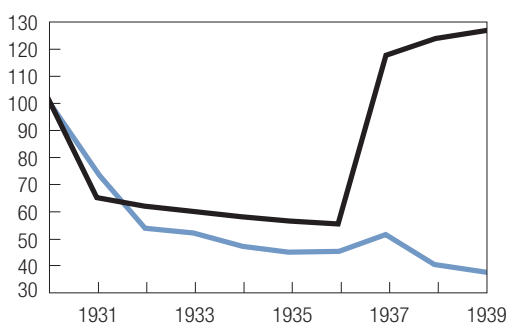

h

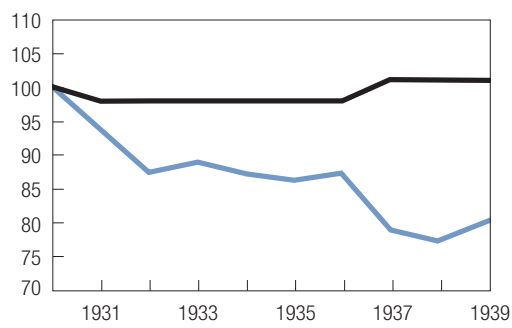

TFP

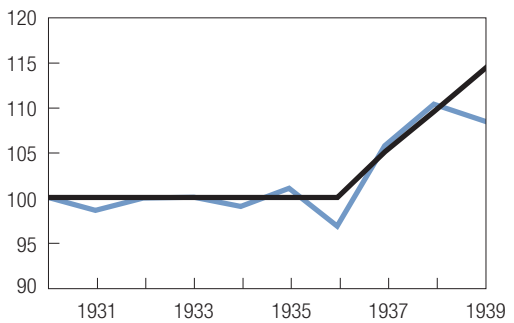

Simulated

Actual

\section{More on Growth Accounting}

We start with some more growth accounting. Assume that for the actual series of inputs, TFP had grown at its steady growth rate during the 1930s. What would have been the path of output? We use the production function of the model economy, taking input variation as given. The path of output is the starred line in Figure 8. About 70 percent of the 1930-32 drop is explained, without any need for the TFP slowdown. 1932-36 is poorly reproduced, meaning that TFP slowdown is needed for this subperiod while, again, the match is good for the cumulative growth between 1937 and 1939. If technological stagnation is needed for 1932-36, it seems to not be the main reason 
Figure 7. Unexpected TFP stagnation with low elasticity, 1930-39
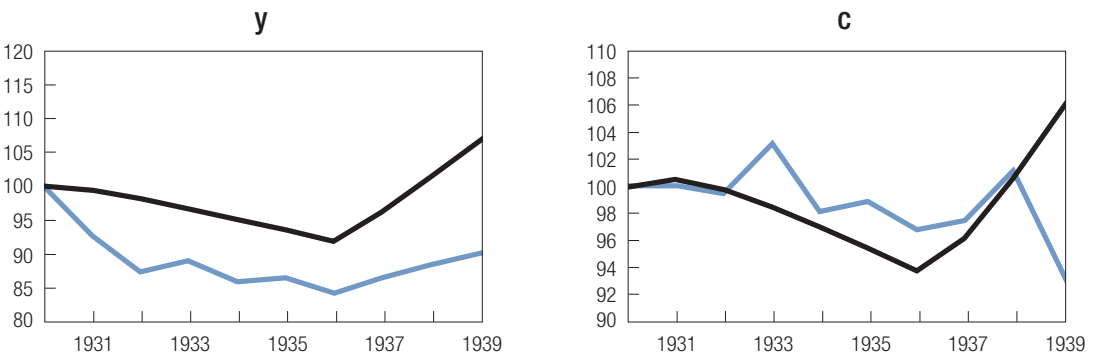

i

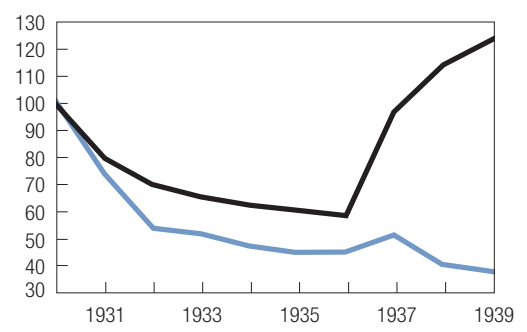

h

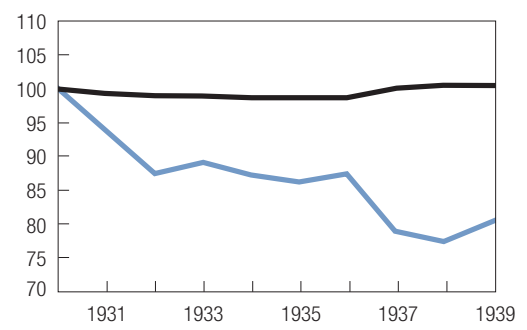

TFP
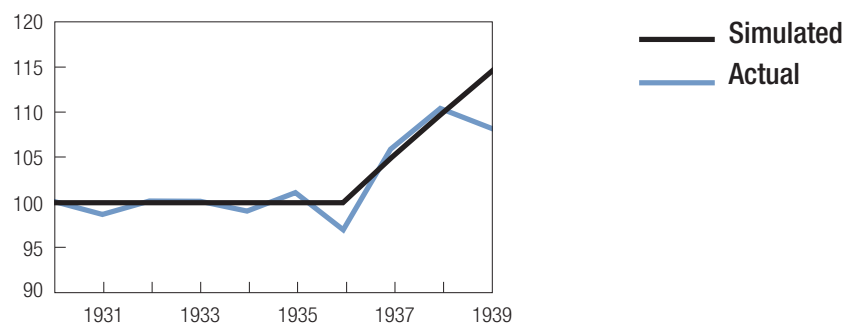

for movements in 1930-32 and 1936-39.

Let us take as given the observation of the stagnation in measured TFP from 1930 to 1936 and ask why we observed such a stagnation, knowing that technology improved in France throughout the century. A natural candidate explanation for this observation, which does not rely on technological stagnation, is technological embodiment. In effect, the 1930s were a period of depressed investment. In a world with embodied technological progress, technological progress does not occur if the economy does not invest, as it is embodied with new vintages of capital. Even though the technological frontier still progresses, the economy does not make use of it, as it does 
Figure 8. Accounted movements in output, 1930-39

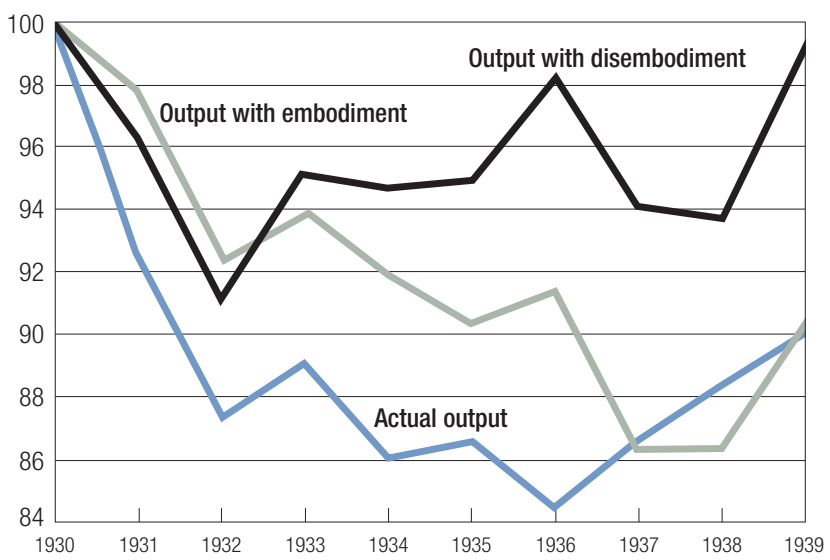

not implement technological progress in production, given the low level of investment. Clearly, if one follows this line of reasoning, one still needs to explain why investment was so low. For now, however, we just examine whether we can explain movements in measured TFP by doing a growth accounting exercise under the assumption that technology is embodied in capital. To keep things simple, we assume in the following that all technical progress is embodied in capital. ${ }^{1}$

Assume that technology is now given by

$$
Y_{t}=A H_{t}^{\alpha}\left(z_{t} J_{t}\right)^{1-\alpha},
$$

where $J$ is the effective capital stock and $A$ is now constant. According to the embodiment assumption, capital $J$ accumulates according to

$$
J_{t+1}=\left(1-\delta_{J}\right) J_{t}+X_{t} I_{t},
$$

where $I_{t}$ is the national accounting measure of investment and $X$ a technological factor that grows at rate $\gamma x$. From these two equations, it is easy to show that along a balanced-growth path, the following relations hold: $\gamma_{Y}=\gamma_{I}=((1-\alpha) / \alpha) \gamma_{X}$ and $\gamma_{J}=(1-\alpha) \gamma_{X}$. The problem with this model is that it is not the one used for national accounting, where capital is measured according to

$$
K_{t+1}=\left(1-\delta_{K}\right) K_{t}+I_{t} .
$$


How can we compute the true capital stock series $J_{t}$ ? Assuming that the economy has been on a steady growth path before 1930, with a growth rate $\gamma_{X}$ for embodied technological progress, one can solve backward the accumulation equation for $J$ to compute $J_{t}$ as the deflated sum of past investments, the deflator taking into account both depreciation and technological progress:

$$
J_{1930}=\frac{I_{1929}}{1-\frac{1-\delta}{\left(1+\gamma_{I}\right)\left(1+\gamma_{X}\right)}}
$$

Once $J_{1930}$ is known, given the series of investment and assuming that $X$ grows at a constant rate, one can use the $J$ accumulation equation to compute a series of $J_{t}$, from 1930 to 1939. Using this series and the series of hours, one can compute a simulated series of output with embodied technological progress. With $\delta_{J}=0.14$ and $\gamma_{I}=0.0298$, one gets the series with circles in Figure 8. This simulated output tracks well the actual one, and no stop nor regression in technological progress is needed (but, of course, it does not explain the movements in investment and hours).

To sum up, independent of the nature of technological progress, embodied or disembodied, input movements are enough to account for most of output movements from 1930 to 1932, whereas TFP stagnation is needed for 1932-36 if we assume that new technology is disembodied. Furthermore, if technological change is embodied in capital, then technological stagnation is not necessary to explain output movements as long as the investment drop can be explained by nontechnological factors. Further, in the model with embodied technological progress, one can use the simulated output to compute a series of measured TFP. Analytically, this series is given by

$$
\Delta \log T F P_{t}=(1-\alpha)\left(\Delta \log J_{t}-\Delta \log K_{t}\right) .
$$

This series is denoted "measured TFP if embodiment" and is represented with stars in Figure 9, along with the standard series for TFP. We basically reproduce TFP stagnation without assuming any stagnation of technological progress, again leaving unexplained the movements in investment and hours.

\section{Summary}

We have shown in this section that technological stagnation of the kind suggested by measured TFP is not enough to account for the French Depression within a standard real business cycle model and that it is not even necessary 
Figure 9. TFP measurement, 1930-39

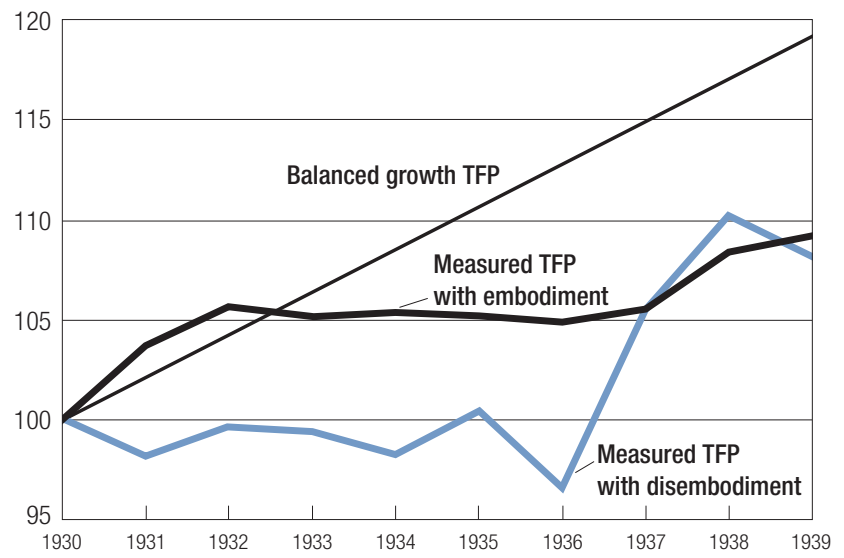

if one is willing to assume that technological progress is embodied in capital. In this later case, however, it is necessary to have an alternative explanation for movements in input. We explore this issue in the next section.

\section{Institutional Change as Possible Explanation}

\section{Change in Steady States}

As we have shown, hours are roughly constant after 1937, 25 percent below their pre-Depression level, whereas output is again growing at its normal growth rate. The French economy after 1936 behaves as if it were again a balanced-growth path, but with a permanent decrease in hours of 25 percent. The Front Populaire of 1936 was the outcome of a decade of transformation of the French economy, with increasing unionization, strikes, and changes in the working of the labor market. In a neoclassical model, such an institutional change - modeled, for example, by increasing the bargaining power of labor suppliers - should lead to a reduction in the same proportion of output (relative to trend) and hours. This is almost what we observe, output being around 30 percent below trend over the same subperiod. Strikingly, the same observation holds for the United States: private hours are around 25 percent below their 1929 level from 1936 to 1939, whereas output is between 25 percent and 30 percent below its trend (see Cole and Ohanian 1999a, Tables 2 and 5). A second striking observation is that in both countries, the investment-output ratio is about 8 percent lower at the end of the episode compared to the pre-Depression level (see Table 5 for France, and Cole and Ohanian 1999a, Table 3, for the United States). 
Cole and Ohanian (1999b) explore the implications of the institutional change associated with the New Deal for the slow recovery of the U.S. economy after 1933. Given the similarities between the French and U.S. cases, we want to explore the possibility of a change in market regulation accounting not only for the slow recovery but also for the entire French episode, and therefore perhaps also for the U.S. Depression. Again, some simple growth accounting shows that this is quantitatively plausible.

Let us take the economy in deviations from its growth trend. Using a Cobb-Douglas technology, the following relation holds:

$$
\Delta \log Y_{t}=\alpha \Delta \log H_{t}+(1-\alpha) \Delta \log K_{t} .
$$

One can also decompose the variation of $K / Y$ into

$$
\Delta \log \left(\frac{K_{t}}{Y_{t}}\right)=\Delta \log Y_{t}-\Delta \log K_{t} .
$$

Putting those two equations together, one gets

$$
\Delta \log Y_{t}=\Delta \log H_{t}+\frac{1-\alpha}{\alpha} \Delta \log \left(\frac{K_{t}}{Y_{t}}\right) .
$$

Along a balanced-growth path, this is also

$$
\Delta \log Y_{t}=\Delta \log H_{t}+\frac{1-\alpha}{\alpha} \Delta \log \left(\frac{I_{t}}{Y_{t}}\right) .
$$

In the French and U.S. cases, one has roughly $\alpha=2 / 3, \Delta \log H_{t}=0.025$ and $\Delta \log \left(I_{t} / Y_{t}\right)=0.08$, and therefore

$$
\Delta \log Y_{t} \approx 0.30 \text {, }
$$

which is basically what we observe in both countries, in deviations from the steady growth path.

Two questions now arise: Why did such changes occur in hours and in the capital-output ratio? Can those changes explain the dynamic response of the economy from one steady growth path to another? While we will not say anything about the fundamental reasons why hours and the capital-out- 
put ratio changed, we explore the second question within the confines of a simple model.

\section{Depression as Transitional Dynamics Path}

The model economy we use here is a simple model with embodied technological progress. Preferences are represented by

$$
V(0)=E_{0} \sum_{t=0}^{\infty} \beta^{t}\left(\log C_{t}+\frac{\theta}{1-\eta}\left((1-H)^{1-\eta}-1\right)\right) .
$$

Technology is Cobb-Douglas. For simplicity, we do not model variability of capital utilization, as it is not necessary for our purpose.

$$
Y_{t}=A H_{t}^{\alpha} K_{t}^{1-\alpha} .
$$

Technological progress is embodied in newly installed capital

$$
K_{t+1}=(1-\delta) K_{t}+X_{t} I_{t},
$$

where $X$ is growing at constant deterministic rate

$$
X_{t}=\gamma X_{t-1} .
$$

The following two first-order conditions of a social planner's problem hold:

$$
\begin{aligned}
\mu_{t} / C_{t} & =\theta\left(1-H_{t}\right)^{-\eta}(1-\alpha) Y_{t} / H_{t}, \\
\frac{1}{C_{t}} & =\chi_{t} E_{t}\left[\frac{\beta}{C_{t+1}}\left((1-\alpha) A_{t+1} K_{t+1}^{-\alpha}\left(X_{t+1} H_{t+1}\right)^{\alpha}+1-\delta\right)\right],
\end{aligned}
$$

where $\mu_{t}$ and $\chi_{t}$ are two exogenous variables that allow us to mimic the long-run effect of institutional change. An increase in bargaining power of the workers will increase $\mu$, whereas an increase in monopolistic power of firms will decrease $\chi$. Both variables are needed to account for both a reduction of steady-state worked hours and the capital-output ratio. Interestingly, a positive shock on $\mu$ and a negative shock on $\chi$ corresponds to Cole and Ohanian's (1999b) modeling of the U.S. New Deal (increase in real wages and cartelization). 

with embodied technological change, 1930
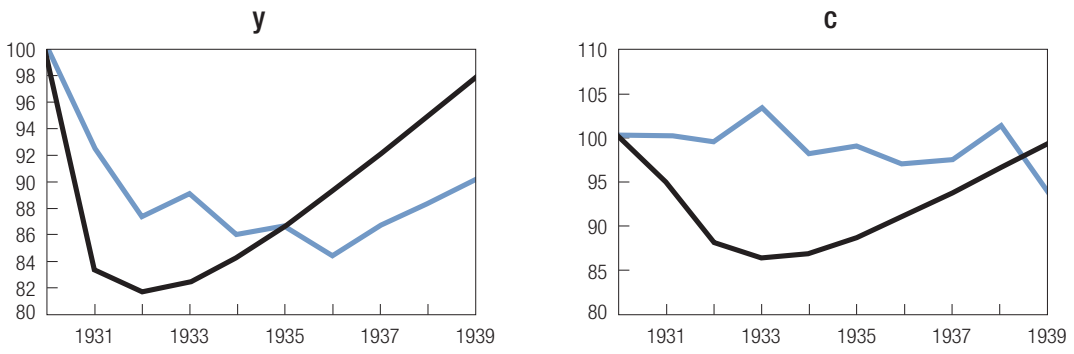

i

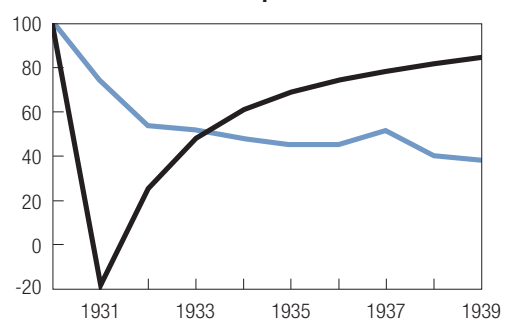

TFP

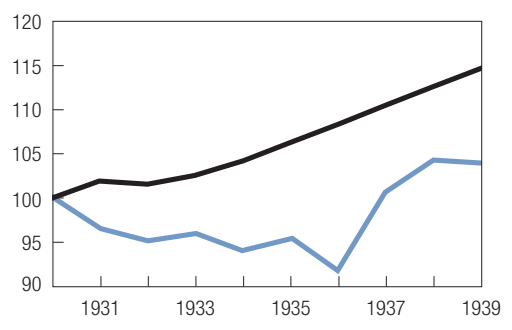

h

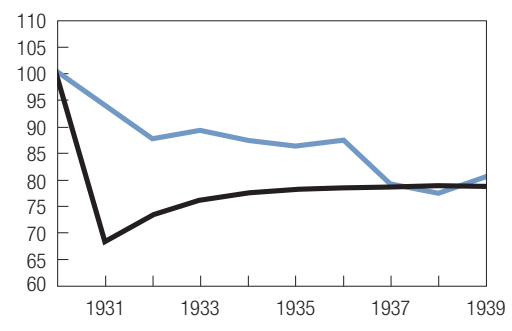

Given the high degree of abstraction in this model, we cannot expect it to match the data exactly. Let us simply assume that both $\chi$ and $\mu$ are equal to one before 1930 and are expected to stay constant. Then an unexpected and permanent shock on $\mu$ and $\chi$ occurs in 1930, with $\Delta \log \mu=0.20$ and $\Delta \log \chi=-0.08$. A positive shock to $\mu$ is interpreted as an increase (effective or expected in 1930) in worker bargaining power or markup, while a negative shock to $\chi$ relates to an increase in cartelization or degree of capital appropriability by workers.

We compute the dynamic response of the economy to these unexpected and permanent shocks in 1930. This response is displayed in Figure 10. 
Note that without any slowdown or regression in technological change, the transitional dynamics is enough to account for a 25 percent decline in output. Because investment collapses after the shock (in an unrealistic way in this experiment), technological progress is no longer incorporated into production and measured TFP stays flat. Accordingly, our experiment should be taken as merely illustrative, but it gives us a direction for future research.

\section{Conclusions}

We have shown that the French Depression of the 1930s had more similarities than differences with the U.S. Depression and that movements in factors of production were sufficient to account for the movement in output, without having to invoke technological regression or stagnation, if a vintage capital model is used. We also show that it is possible to understand the French Depression as an example of transitional dynamics between two steady states, the final one being one with less worked hours and a smaller investment-output ratio. A model of institutional change, of the labor market as well as of the capital market, that mimics the transition between those two steady states is qualitatively and quantitatively a possible explanation for the economic path of the 1930s. Although we have not provided a fully specified model, we think it is an interesting avenue that we would like to pursue in the near future.

\section{Data Appendix}

As mentioned earlier, the data we use in this study have been compiled by Pierre Villa (1993). He proposes a very detailed description of sources and methods of construction of the database, including national income and product accounts for the twentieth century in France. Here, we briefly summarize some of Villa's work.

The GDP series that we use for 1919-39 is constructed as the sum of final demands. When we compute century-wide statistics (GDP growth rate, income share of labor, TFP growth rate), we use a production approach evaluation of GDP that is homogeneous for the entire sample.

The employment series used come from two different sources: first, census data for the years 1921, 1926, 1931, and 1936, at the two-digit level; second, quarterly surveys (Enquêtes des Inspecteurs du Travail) from 1914 to 1939 for the private sector. Hours series are obtained by multiplying employment by the average workweek length. Information concerning workweek length comes first from a survey conducted in the manufacturing industry from 1931 to 1939 for more than one hundred worker establishments. From this survey, it appears that the workweek length is close to the legal maximum. Information about the legal maximum is then used for the previous years, in addition to survey information from the Ministry of Labor from the years 
$1920,1924,1929$, and 1931. For services, information is not as good, and data have been interpolated between the years 1920, 1924, 1929, and 1931. For civil servants, it has been assumed that the workweek length was equal to the legal maximum. As no information is available for the agricultural sector, the workweek length is assumed to be equal to the economy-wide average.

The capacity utilization series is provided by Villa, and we have not been able to find how it was constructed.

\section{Notes}

Reprinted from Review of Economic Dynamics, Vol. 5, Paul Beaudry and Franck Portier, "The French Depression in the 1930s," pages 73-99, copyright 2002, with permission from Elsevier.

We would like to thank Timothy Kehoe and Ed Prescott for having initiated this project, and Kevin Murphy, Pedro Amaral, Jim MacGee, and an anonymous referee for helpful comments.

1. An evaluation of the strength of embodied technological progress is given by the price of investment relative to the price of output. Over 1919-39, the relative price of equipment declined at a rate of -1.63 percent, which is an indicator of vintage capital.

\section{References}

Asselain, Jean-Charles. 1995. Histoire économique du XX siècle: La montée de l'Etat (1914-1939). Paris: Presses des Sciences Po et Dalloz.

Beltran, Alain, and Pascal Griset. 1994. L'économie française, 1914-1945. Paris: Armand Colin.

Cole, Harold L., and Lee E. Ohanian. 1999a. The Great Depression in the United States from a neoclassical perspective. Federal Reserve Bank of Minneapolis Quarterly Review 23 (Winter): 2-24.

1999b. New Deal policies and the persistence of the Great Depression: A general equilibrium analysis. Working Paper 597. Federal Reserve Bank of Minneapolis.

Flamant, Maurice. 1989. Dynamique économique de l'histoire: Deux siècles de progrès. Paris: Monchreisten.

Greenwood, Jeremy, Zvi Hercowitz, and Gregory Huffman. 1988. Investment, capacity utilization, and the real business cycle. American Economic Review 78 (June): 402-17.

Hautcoeur, Pierre-Cyrille. 1997. The Great Depression in France (1929-1938). In Business cycles and depressions: An encyclopedia, ed. David Glasner. New York: Garland.

Prescott, Edward C. 1999. Some observations on the Great Depression. Federal Reserve Bank of Minneapolis Quarterly Review 23 (Winter): 25-29.

Villa, Pierre. 1993. Une analyse macro-économique de la France au XXème siècle. Paris: CNRS Éditions. 